\title{
Extracellular Proteolytic Activity in the Surface Sediment of a Eutrophic Inlet
}

\author{
ARUn B. PATEL ${ }^{1}$, KIMIO FUKAMI ${ }^{1 *}$ and TOShitAKA NishiJima ${ }^{1}$ \\ ${ }^{1}$ Laboratory of Aquatic Environmental Science (LAQUES), Kochi University, Otsu 200, Monobe, Nankoku, Kochi \\ 783-8502, Japan
}

(Received May 17, 2000-Accepted December 1, 2000)

The potential aminopeptidase activity (APA) in surface sediment $(0-1 \mathrm{~cm})$, and important ecological factors of a eutrophicated inlet were monitored for one and a half years on a weekly to biweekly basis to elucidate the fluctuations in extracellular hydrolysis of protein during an annual cycle, and main regulating factors on an annual and/or a seasonal basis. APA was estimated in sediment slurry prepared with unamended bottom water, as the $\mathrm{V}_{\max }$ of the rate of the enzymatic hydrolysis of a coumarine derivative fluorophore at in situ temperatures. APA varied 5-6 fold during the study period with highest values (225-275 nmole AMC h ${ }^{-1} \mathrm{~g}^{-1}$ dry weight) during September-October or early June when the temperature was $22-28^{\circ} \mathrm{C}$ and dissolved oxygen concentrations (DO) (2-4 $\mathrm{mg} \mathrm{L}^{-1}$ ) in overlying bottom water were high, and much lower values (ca. 50 nmoles $\mathrm{AMC} \mathrm{h}^{-1} \mathrm{~g}^{-1} \mathrm{dry}$ weight) in July-August or December-February. On an annual basis, APA correlated only marginally $(\mathrm{p}<0.05 ; \mathrm{r}$ $=0.25$ ) with the protein content of the surface sediment and not at all with any other variables. However, it showed highly significant correlations $(\mathrm{p}<0.001)$ with temperature $(\mathrm{r}=0.81)$, and protein content $(0.65)$ in mid December-early June, when temperatures were relatively low (ca. $12-22^{\circ} \mathrm{C}$ ) and DO was abundant $(\mathrm{ca} .2-6 \mathrm{mg}$ $\mathrm{L}^{-1}$ ) in overlying bottom water.

Key words: surface sediment, aminopeptidase activity, semi-enclosed eutrophic ecosystem, sediment slurry

The intensive farming of fish in addition to terrestrial process-intensification has led to the discharge of a considerable amount of nutrient effluent into the environment ${ }^{12,17)}$. These allochthonous materials, which are mostly of particulate and polymeric forms, eventually move from the water column to the underlying sediment especially in shallow water ecosystems making the sediment rich in organic matter ${ }^{3,21)}$. Therefore, the sediment of shallow water ecosystems is a site of intense biogeochemical activity ${ }^{38)}$, and bacteria-mediated decomposition of allochthonous materials is central to the energy flow and nutrient recycling in a variety of aquatic systems ${ }^{20}$.

The rate-limiting step in the decomposition and mineralization of polymeric organic matter is the extracellular hydrolysis of macromolecules such as proteins into smaller

\footnotetext{
* Correspondingauthor; E-mail: fukami@cc.kochi-u.ac.jp, Tel: +81-88-864-5152, Fax: +81-88-864-5197
}

molecules. Extracellular hydrolysis is an indispensable step in the degradation of organic matter because bacterial cells can only take up small molecules ${ }^{1024)}$. The importance of hydrolytic activity in sediment for the recycling of organic matter has been recognized in recent years, and several studies have been undertaken to estimate the activity in various aquatic environments ${ }^{31,34,40)}$. However, measurements have frequently been made only during arbitrarily selected periods of the year ${ }^{40)}$ or else at intervals as long as one or two months ${ }^{7,28}$. Moreover, they have often been done in isolation with little consideration given to the monitoring of ambient variables especially in overlying water. It is to be pointed that there exists a relatively close coupling of heterotrophic processes between the water column and sediment in shallow water ecosystems ${ }^{8}$. Therefore, our understanding of the general relationships between the hydrolytic activity in sediment and environmental variables is still limited, and especially poor in the case of ecosystems 
which experience marked alterations in environmental conditions, and undergo thermal or density stratification within an annual cycle due to their geographical location.

We evaluated aminopeptidase activity (APA) in surface and bottom waters ${ }^{37)}$, and surface sediment $(0-1 \mathrm{~cm})$ of Uranouchi Inlet, Japan, simultaneously, as a measure of the extracellular hydrolysis of protein. Uranouchi Inlet is a shallow water eutrophic coastal ecosystem in which a great deal of intensive fish rearing in cages is practiced. The estimations were done on a weekly to biweekly basis, accompanied by the monitoring of important ecological variables in water as well as sediment components including temperature, dissolved oxygen (DO), bacterial abundance, and nutrient concentrations. The main objectives were to investigate the fluctuations in the extracellular hydrolysis of protein or peptides, and impacts of ecological variables on the hydrolysis at the study site. In the present paper, we report results pertaining to the surface sediment, and try to investigate the correlations between APA and ecological variables on an annual, and/or a short term basis.

\section{Materials and Methods}

\section{Study site and sample collection}

The sampling station is located in the center of Uranouchi Inlet, Kochi Prefecture, Japan (Fig. 1). A description of the study site can be found in earlier publications ${ }^{14,15,37)}$. In brief, the site is a semi-enclosed shallow water (depth $\sim 16-17 \mathrm{~m}$ ) coastal ecosystem which witnesses only limited water exchange ${ }^{15}$, and experiences pronounced density stratification $^{14,37)}$ during an annual cycle. Furthermore, the inlet contains a large number of fish rearing cages from which a considerable amount of nutrients is discharged leading to eutrophication of the inlet.

The core sediment samples were collected on a weekly to biweekly basis by using a K-K core sampler. Upon retrieval of the sampler, the redox potential (Eh), $\mathrm{pH}$, and dissolved oxygen (DO) of the overlying water $(10 \mathrm{~cm}$ above the sediment surface) were read immediately by using an ORP meter (TOA, RM-12P), pH meter (Horiba, D-13), and DO meter (Horiba DO meter OM-14)), respectively. Utmost care was taken to avoid any disturbance in the sediment-water interface. Thereafter, water was siphoned out and the Eh of the surface sediment $(0-1 \mathrm{~cm})$ was measured using the ORP meter. Then, the surface layer of the core $(0-1 \mathrm{~cm})$ was sectioned and collected into an acid-washed small plastic bottle. Sections from at least three cores were pooled together to obtain a better representative sample. This pooled sample was used for all the analyses including APA measurements. Water samples $(16 \mathrm{~m})$ were collected using Kitahara (1 L) or Niskin (5 L) water samplers. All the samples including water and sediment were brought back to the

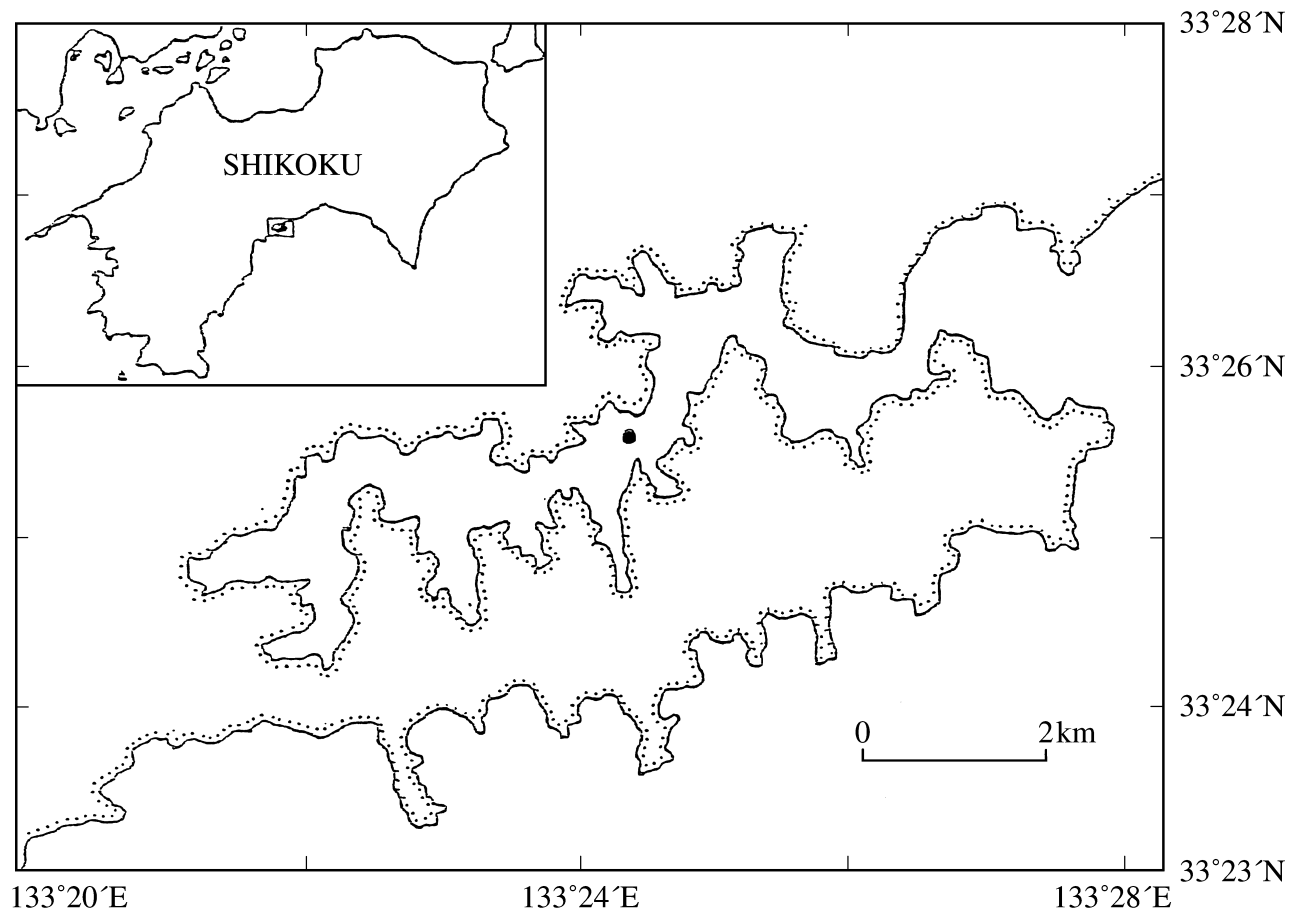

Fig. 1. Location of the sampling station in Uranouchi Inlet of Kochi Prefecture, Japan. 
aboratory on ice (temperature $\sim 5-10^{\circ} \mathrm{C}$ ), and shielded from light, within 1-2 hours of collection.

\section{Monitoring of physicochemical and biological variables at the study site. Water}

A CTD system (Idronaut, model no. $301 \mathrm{~S}$ ) was used to measure in situ temperature, DO, $\mathrm{pH}$, salinity, and redox potential of the water column at the sampling site on each sampling occasion. We also monitored other variables including dissolved nutrient concentrations (after GF/F filtration) (automatic analyzer; Bran+Luebbe TRAACS 800), bacterial abundance ${ }^{13,41)}$, and chlorophyll concentrations ${ }^{6)}$.

\section{Sediment}

Sediment subsamples (about $5 \mathrm{~g}$ wet weight) were analyzed for water content by drying at $80^{\circ} \mathrm{C}$ until a constant weight was achieved (usually 18-24 hours) ${ }^{5}$. The organic matter in the sediment was measured as ignition loss by burning the oven-dried sediment samples at $550^{\circ} \mathrm{C}$ for $5-6$ hours $^{5)}$ in a blast furnace. The protein content of the sediment (usually $0.5 \mathrm{~g}$ wet weight) was extracted into $1.0 \mathrm{~N}$ $\mathrm{NaOH}$ for 18 hours at $37^{\circ} \mathrm{C}$ with shaking (on a reciprocatory shaker with 55 oscillations per minute), and estimated spectrophotometrically ${ }^{26}$. Bacterial abundance was determined by the direct-count method using epifluorescence microscopy after staining with DAPI ${ }^{41,43,45,49)}$. The bacteria were dispersed from their sites of attachment by sonicating the sediment subsamples in ultrasonic cleaner $(930 \mathrm{~W})$ for 30 minutes with tetra sodium pyrophosphate $\left(\mathrm{Na}_{4} \mathrm{P}_{2} \mathrm{O}_{7}\right.$; final concentration, $0.01 \mathrm{M})^{45)}$, and then stained with DAPI $(5 \mu \mathrm{g}$ $\mathrm{mL}^{-1}$ ) for 20 minutes at $4^{\circ} \mathrm{C}$.

\section{Standardization of Enzyme Assay and Estimation of APA}

We estimated potential aminopeptidase activity (APA) in slurries of surface sediment $(0-1 \mathrm{~cm})$ as $\mathrm{V}_{\max }$ of hydrolysis of a fluorogenic substrate analog, 7-L-Leucyl-4-methyl coumarinylamide (Leu-MCA; peptide Inc.) ${ }^{18,19)}$ by utilizing the enzyme assay. Slurries were prepared by adding fresh sediment to unamended in situ bottom water $(16 \mathrm{~m})$ (dilution, $1: 250, \mathrm{~W} / \mathrm{V})$. We used the multi-substrate concentration method $^{23)}$ and conducted standardization experiments to investigate the dependence of APA upon the range of substrate concentrations used by introducing concentrations of Leu-MCA ranging $0.5-80.0 \mu \mathrm{M}$ (final concentration) prepared in dimethyl sulfoxide into the slurries, and following the time-course responses for each substrate concentration. APA was calculated as the $\mathrm{V}_{\max }$ of the rate of release of AMC in unit time per unit weight (nmole AMC $\mathrm{h}^{-1} \mathrm{~g}^{-1}$ ) by using a linearized form of the Michaelis-Menten equation ${ }^{11)}$.
As slurries were prepared using unamended in situ bottom water, to calculate APA in the sediment component only, we estimated the APA in bottom water together with sediment slurry. Aliquots of $15 \mathrm{~mL}$ of the slurry and the unamended bottom water were poured into acid-washed glass incubation bottles and were acclimated at in situ temperatures (in a water bath) for 20 minutes before starting the enzymatic reaction. The head space of the incubation bottles was occupied by atmospheric air. The enzyme assay was started by addition of multiple concentrations of substrate analog $(2.5,5.0,10.0,20.0,40.0 \mu \mathrm{M}$, final concentration) usually within 2-3 hours of sampling, and incubation time was kept relatively short (within $45 \mathrm{~min}$.) in order to minimize bottle effect ${ }^{46)}$ or nonlinear metabolic responses ${ }^{16}$. No illumination or shaking was provided during the incubation. The assays for the slurry were conducted usually in triplicate (at least duplicate), and those for the bottom water usually in duplicate. At least 3 time points in addition to the zero-time point were obtained at each substrate concentration. To obtain the zero-time point and desired time points, we prepared supernatant for reading the fluorescence in a spectrofluorometer (Shimadzu RF-500 calibrated against the standard chemical compound 7-amino-4-methylcoumarin, AMC), and calculated net fluorescence and APA in the manner described earlier ${ }^{37)}$. The APA in the sediment component was calculated on a per unit fresh weight basis by subtracting the mean APA in bottom water from that in slurry, and multiplying by the dilution factor (nmole AMC released $\mathrm{g}^{-1}$ wet weight $\mathrm{h}^{-1}$ ), and was reported on a dry weight basis after taking the water content of the sediment into account.

\section{Statistical analysis}

A simple linear regression analysis was used to investigate the correlations between APA, and ecological variables at the study site. Data for bacterial properties including abundance and APA were transformed to natural $\operatorname{logs}$ to equalize the variance. The significance of a relationship was determined by t-test. Furthermore, regression analyses were carried out separately for 2 subsets of data of APA and ecological variables viz. (1) mid December-early June, when ambient temperatures were relatively low $\left(12-22^{\circ} \mathrm{C}\right)$ but there was abundant DO ( $\left.\geq 2 \mathrm{mg} \mathrm{L}^{-1}\right)$, and (2) mid JuneAugust-September, when temperatures were relatively high $\left(23-28^{\circ} \mathrm{C}\right)$ but bottom water had low DO $\left(\leq 1 \mathrm{mg} \mathrm{L}^{-1}\right.$, except for sudden changes as a result of disturbances such as typhoons) to elucidate if certain variables regulated APA on a short-term basis. 


\section{Results}

\section{Ecological characteristics}

Surface sediment at the study site consisted mostly of silt and clay with almost no sand and a water content averaging about $76 \%$ of sediment wet weight during the study period. Furthermore, the surface sediment was considerably rich in organic matter and nitrogen as indicated by the relatively high ignition loss $(8-12 \%)$ (data not shown), and protein content (mostly $8-10 \mathrm{mg} \mathrm{g}^{-1}$ dry weight) (Fig. 2), respectively. Bacterial abundance (DAPI counts) in the surface sediment was also high, being in the order of $10^{10}$ cells $\mathrm{g}^{-1}$ dry weight with most values between $2.0-3.0 \times 10^{10}$ cells $\mathrm{g}^{-1}$ (Fig. 3). Taken together, the protein content and the bacterial abundance at the study site indicate that bacterial mass contributes on average to less than $5 \%$ of the protein content (taking a conversion of $20 \mathrm{fg} \mathrm{cell}^{-1}$ ). This means that most of the protein is of allochthonous origin and is available for bacterial hydrolysis.

The appearance of the surface sediment varied from brownish to dark black (July-August) during the study period, and primarily corresponded to the ambient temperature and dissolved oxygen concentration in the bottom environment. When temperatures were relatively low, and DO concentrations high in the bottom environment, viz. late autumn to winter (November-February), surface sediment was mostly brownish. However, when the situation was reversed during the summer, viz. significantly high temperatures but relatively low DO concentrations (July-August) (Fig. 4), an obnoxious smell usually accompanied the surface sediment which was black in appearance and redox potential (Eh) was very low (less than $-350 \mathrm{mv}$ ), indicating that the surface sediment was highly anoxic and/or reduced (Fig. 5). Notably, redox potential indicated that the sediment surface was mostly anoxic and/or reduced throughout the study period (Fig. 5). In regard to the nutrient contents of bottom water, relatively high dissolved inorganic nitrogen (DIN; sum of ammonium, nitrite, and nitrate) (ca. 5-14 $\mu \mathrm{M}$ ), and phosphorous (DIP) (ca. 1-3 $\mu \mathrm{M}$ ) concentrations were obtained when the water column was stratified in the summer, but values were considerably lower (DIN; 1-3 $\mu \mathrm{M}$, and DIP; $0.1-0.8 \mu \mathrm{M}$ ) during the winter (Patel et al. 2000). Chlorophyll a in bottom water was rather low especially during summer (usually $<1 \mu \mathrm{g} \mathrm{L}^{-1}$ ), and ranged 0.2 $7.9 \mu \mathrm{g} \mathrm{L}^{-1}$ during the study period.

\section{Standardization of the enzyme assay and estimation of APA}

The activity responses for multiple substrate concentrations ranging $0.5-80.0 \mu \mathrm{M}$ were linear up to 30 minutes (Fig. 6). For estimations of APA, substrate concentrations

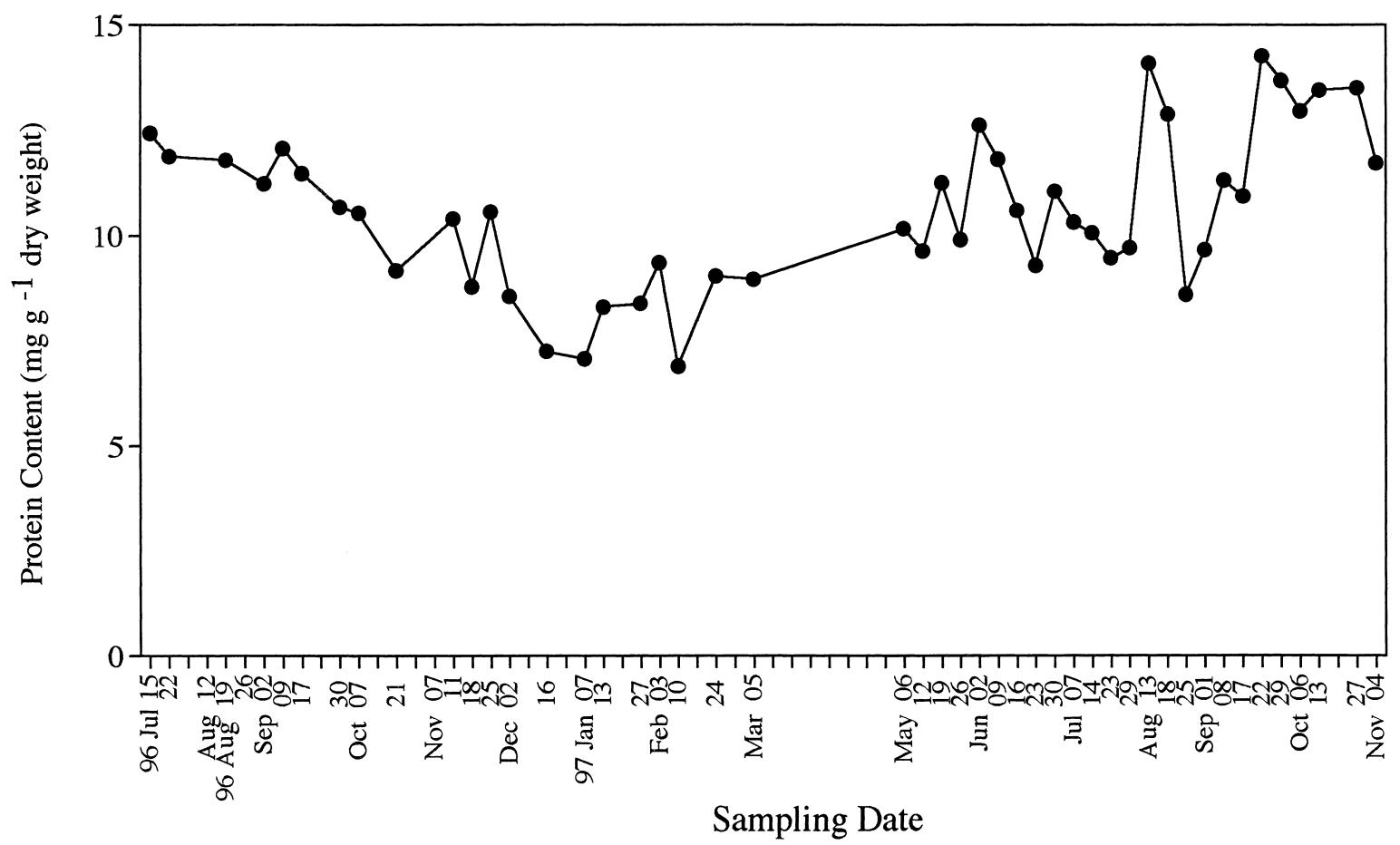

Fig. 2. Seasonal variation in the protein content of the surface sediment $(0-1 \mathrm{~cm})$ at the sampling site. 


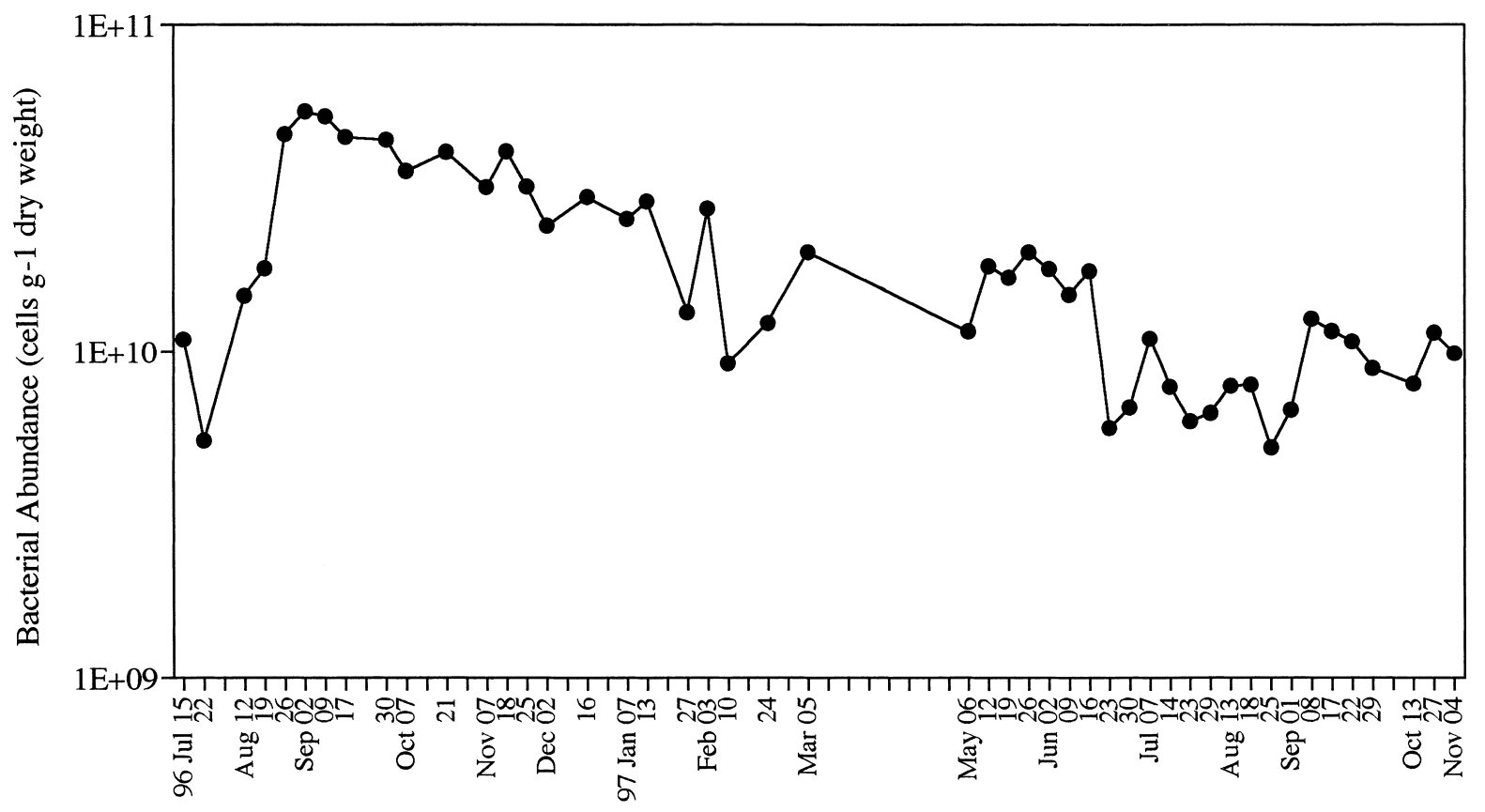

Sampling Date

Fig. 3. Seasonal variation in the bacterial abundance in the surface sediment $(0-1 \mathrm{~cm})$ at the sampling site.

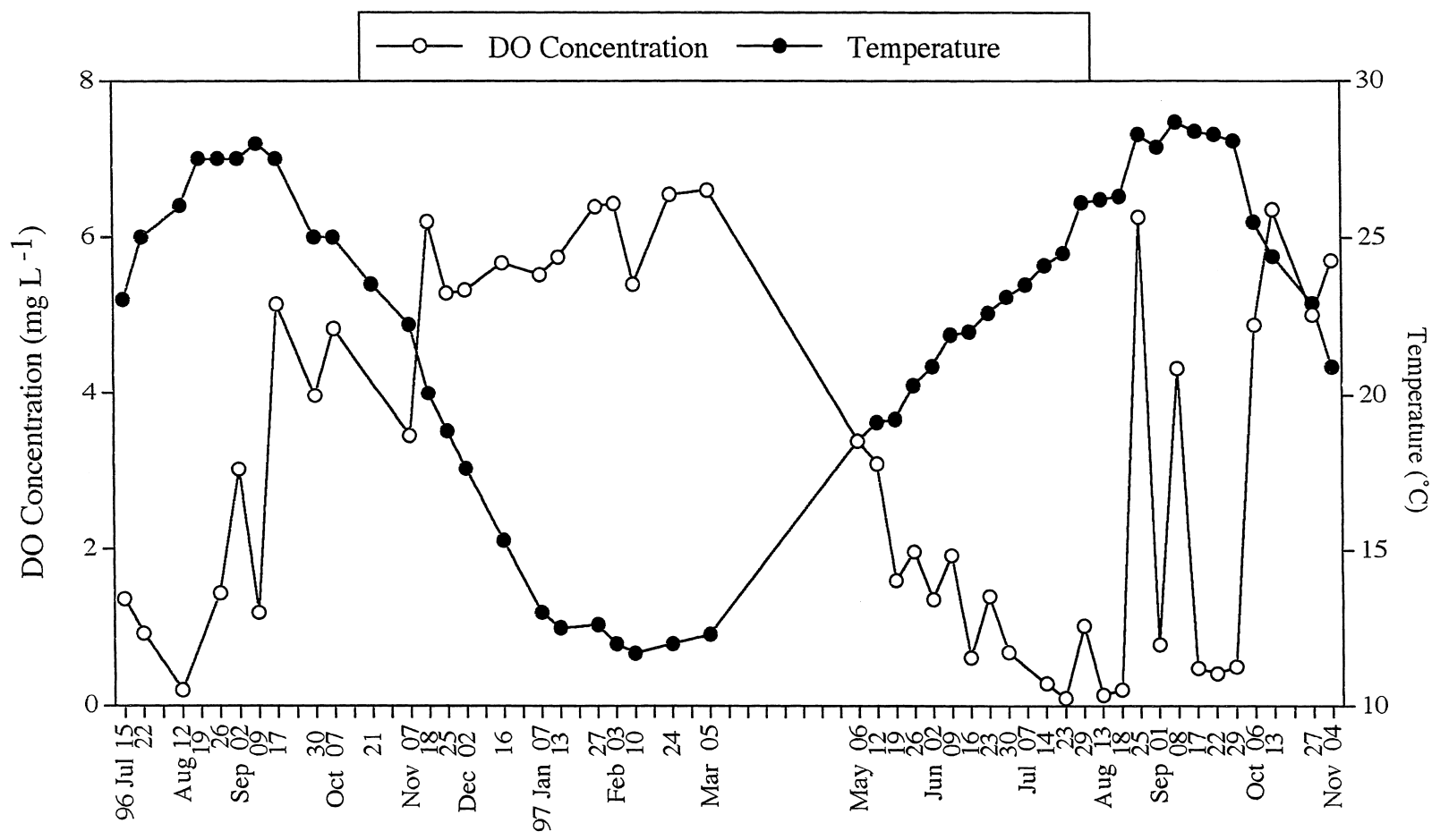

Sampling Date

Fig. 4. Seasonal variations in dissolved oxygen (DO) concentration $(\bigcirc)$ and temperature $((\bullet)$ in overlying bottom water $(\sim 10 \mathrm{~cm}$ above the surface sediment) at the sampling site. 


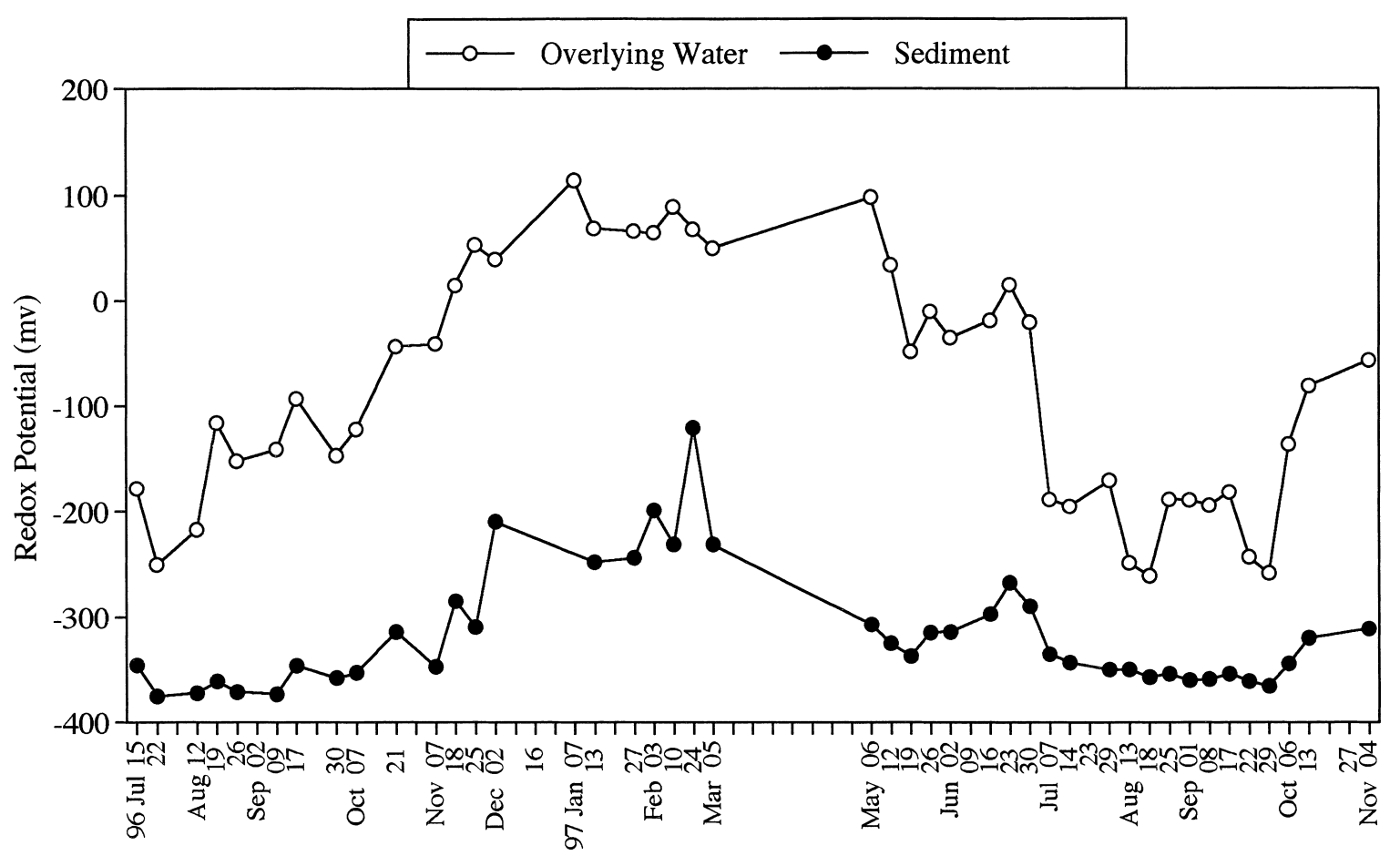

Sampling Date

Fig. 5. Seasonal variations in the redox potential (Eh) of overlying bottom water $(\sim 10 \mathrm{~cm}$ above the surface sediment) $(\bigcirc)$ and surface sediment at the sampling site.

ranging 2.5-40.0 $\mu \mathrm{M}$ were used throughout the study. Additional experiments showed that the activity response was linear for up to 90 minutes at substrate concentrations of

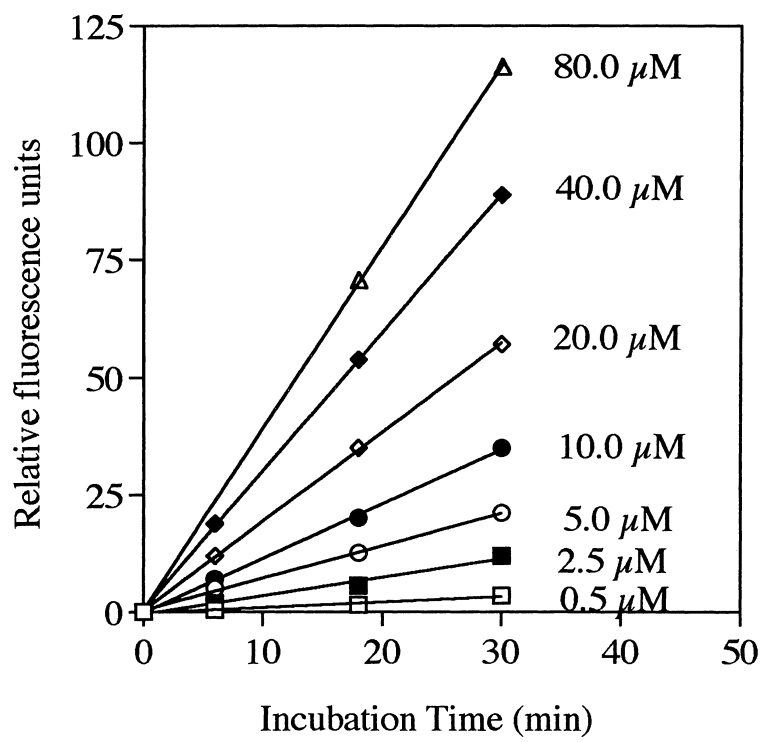

Fig. 6. Hydrolytic activity as a function of substrate concentration and incubation time in the slurry of surface sediment $(0-1 \mathrm{~cm})$.

\section{5-40.0 $\mu \mathrm{M}$ (data not shown).}

Relatively high values of APA ranging 225-275 nmole $\mathrm{AMC} \mathrm{h}^{-1} \mathrm{~g}^{-1}$ dry weight, although short lived, were detected in autumn (September-October) and early summer (early June) (Fig. 7) when the temperature was relatively high $\left(22-28^{\circ} \mathrm{C}\right)$ and the dissolved oxygen concentration moderate $\left(2-4 \mathrm{mg} \mathrm{L}^{-1}\right)$ in the bottom environment (Fig. 4). In general, APA declined considerably during the winter (December-February) and summer (July-August) to reach values as low as about 50 nmoles $\mathrm{AMC} \mathrm{h}^{-1} \mathrm{~g}^{-1}$ dry weight which is less than half of the annual mean value (Annual mean APA; 125 nmoles AMC h${ }^{-1} \mathrm{~g}^{-1}$ dry weight), and less than one fifth or $20 \%$ of that during autumn or early summer. Furthermore, we had estimated APA in deeper sections of the sediment on certain sampling occasions, and observed a significant and rather abrupt decline in activity (on a dry weight basis): $35 \%$ at $1-2 \mathrm{~cm}, 80 \%$ at $2-3 \mathrm{~cm}$, and $99-100 \%$ at $10-$ $11 \mathrm{~cm}$ compared to at the surface (data not shown).

\section{Discussion}

The present study deals with the quantitative fluctuations in potential extracellular hydrolysis of polymeric nitroge- 


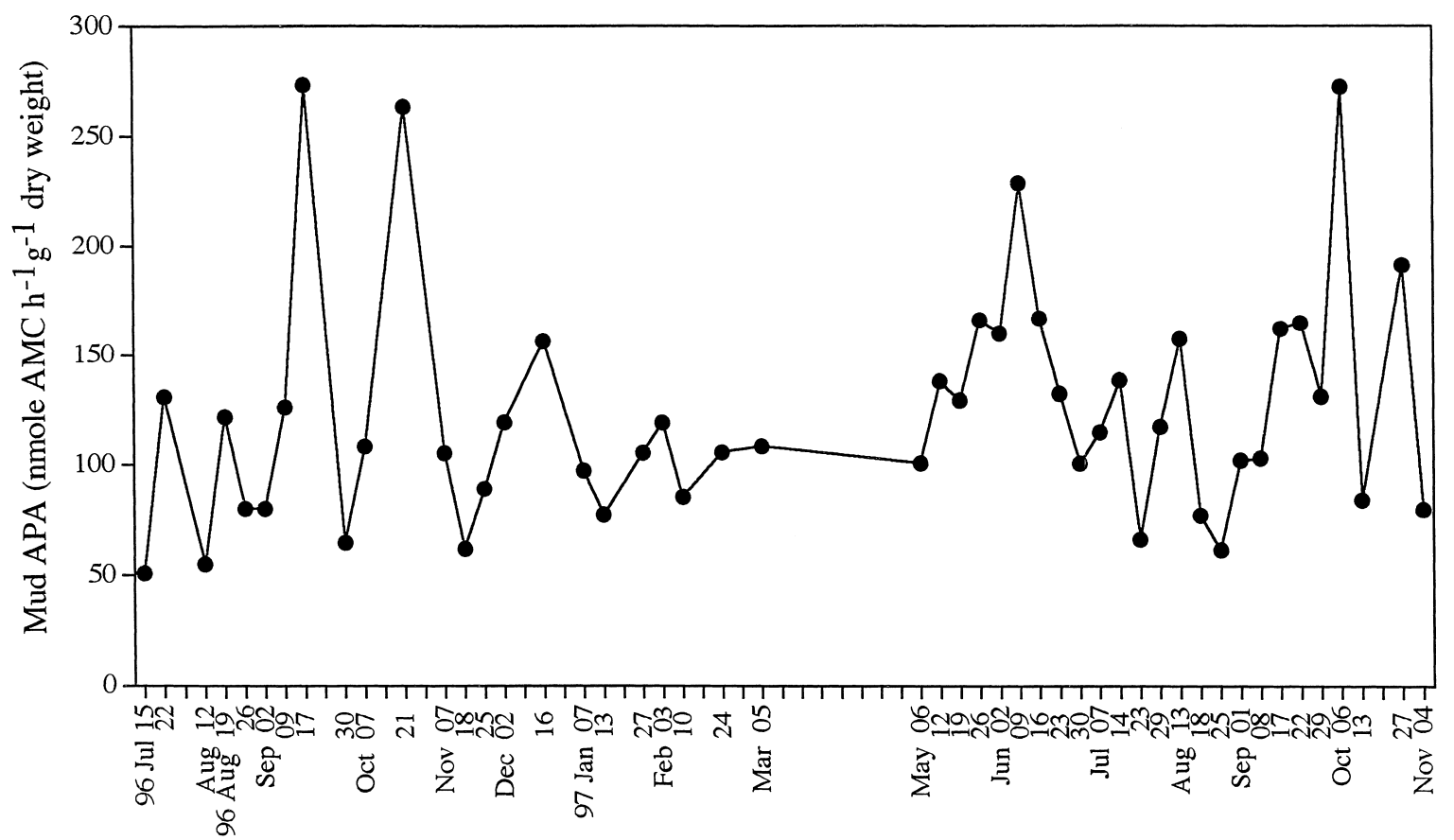

Sampling Date

Fig. 7. Seasonal changes in the potential aminopeptidase activity (APA) in the surface sediment $(0-1 \mathrm{~cm})$ at the sampling site.

nous compounds such as protein and peptides in surface sediment, and the impact of environmental variables on the hydrolysis on an annual and/or a short term basis. Our findings have important implications for the understanding of degradation of proteins and peptide which form one of the major components of effluent discharge from fish farms $\mathrm{s}^{29)}$, and how it is regulated. The activity was estimated as extracellular hydrolysis of protein by assays based on the cleavage of peptide bonds of Leu-MCA, a fluorogenic model substrate that is hydrolyzed by non-specific peptidases ${ }^{19}$. We emphasize, however, that at present there is no standard method to estimate the activities in sediment. Researchers for instance have measured the fluxes of oxygen and carbon dioxide $^{14)}$, the rates of nucleic acid synthesis ${ }^{35,47)}$, and the extracellular hydrolytic activities ${ }^{28,40}$, to evaluate the heterotrophic processes in the sediment. Therefore, any comparisons with results from studies using other methods or model substrates for instance should be made with caution. In fact, even for measuring the extracellular hydrolytic activities, there is no standardized protocol in regard to the substrate analog used and its concentration, incubation temperature and duration, sample volume or processing of the tested material ${ }^{40)}$. Furthermore, confusion still persists over the assay conditions: "should assays be performed according to well established principles of enzymology (i.e. excess substrate, optimum $\mathrm{pH}$ and temperature, shaken reaction mixture) or in conditions imitating to those encountered in an aquatic environment (i.e. sub-optimal and fluctuating physical conditions, stationary incubations)?"'). An agreement is yet to be arrived at, however, in the present study, assays were conducted in conditions imitating those in the field (with ambient water, in situ temperature, and no shaking or illumination).

We estimated the APA in surface sediment $(0-1 \mathrm{~cm}$ depth horizon) because it is a site of intense biological activity where the bulk of mineralization takes place ${ }^{4}$, and because rather abrupt decreases in APA have been observed at a depth of as shallow as $2-3 \mathrm{~cm}^{28}$. In the present study, we observed a similar trend, viz. considerably high APA in surface sediment $(0-1 \mathrm{~cm})$ compared to depths of $1-2,2-3$, and $10-11 \mathrm{~cm}$. We estimated the APA in the slurries of the surface sediment ${ }^{28,40)}$ rather than in undisturbed cores to avoid problems related to different diffusion rates and the unequal distribution of substrates ${ }^{40}$. It should be emphasized however that unlike previous studies in which sterilized ambient water was used for making the slurries ${ }^{28,34,40)}$, we employed unamended bottom water taking into consideration the close interactions between the heterotrophic processes of water and sediment in shallow water ecosystems ${ }^{8)}$. To our knowledge, this is the first study to do this. Never- 
theless, it should be conceded that the use of an artificial substrate, the slurry conditions, and the calculation of $\mathrm{V}_{\max }$, mean that this assay provides no more than an estimate of potential in situ APA.

In general, the black appearance of the surface sediment accompanied by the obnoxious smell, and the rather high negative redox potential $(<-300 \mathrm{mv})$ throughout the study period indicate that the present site is eutrophicated and the surface sediment is mostly in an anoxic and/or reduced state. Furthermore, the low redox potential, relatively high bacterial abundance, and protein content per unit dry weight compared to other studies ${ }^{1,3,4,28)}$, are consistent with this conclusion. Therefore, it is not surprising that APA was significantly higher (per unit dry weight) at the study site than on an intertidal mudflat ${ }^{28}$. Notably however, the APA in surface sediment showed limited seasonality and varied only by 5 to 6 -fold during the study period. Interestingly, the APA in the water column had exhibited a much more pronounced seasonality during the same period; varying in surface water $(2 \mathrm{~m})$ about 40 -fold, and in bottom water about 12 -fold ${ }^{37)}$. This may indicate that heterotrophic activities in bottom environments are less affected by the seasonal changes in ecological variables than those in surface environments. Nonetheless, considerably high values of APA (ca. 225-275 nmole AMC h-1 $\mathrm{g}^{-1}$ dry weight) were observed in the surface sediment either in autumn (September-October) or in early summer (early June) when the temperature was relatively high $\left(22-28^{\circ} \mathrm{C}\right)$ and the DO concentration moderate $\left(2-5 \mathrm{mg} \mathrm{L}^{-1}\right)$ in overlying bottom water. It is reasonable to assume that aerobic or facultative aerobic microorganisms which are known to possess significantly greater activity than their anaerobic counterparts ${ }^{42}$ ) would have operated under oxygen-mediated metabolic pathways, and enhanced the APA in response to favorable ecological conditions (in bottom environments). Hoppe ${ }^{18)}$ suggested that more active bacteria may have greater protease activities. It may be also of relevance that at the present site, the rate of release of dissolved inorganic nitrogen from intact core sediment into the water was markedly higher during the autumn (September-October) than in late summer (August) or winter (January-February) (manuscript under preparation). On the other hand, we observed sudden drops in APA during both years of the study. These drops would probably be due to the dynamic influences of environmental factors, for example, an accumulation of dissolved inorganic nutrients such as nitrogen, as high concentrations of inorganic nitrogen are suspected to reduce the $\mathrm{APA}^{10)}$, or reduced concentrations of readily available substrate viz. protein content in the vicinity of the microorganisms, as a substantial fraction of the extracellular enzymes are bound to the cell membranes ${ }^{18,27,33)}$, and thus only a relatively small surface area can be attacked by the hydrolytic enzymes ${ }^{23}$.

In general, APA in the surface sediment did not correlate well with any ecological variable on an annual basis. The protein content did show a marginally significant and quite weak correlation $(\mathrm{p}<0.05 ; \mathrm{r}=0.26)$ (data not shown) however. The correlations between proteolytic activitiy, and variables such as substrate concentration, and bacterial abundance, have varied with reports ${ }^{7,28,30,32,42)}$. Considering that the present study site experiences pronounced alterations in ecological conditions during an annual cycle, it is quite likely that the effect of one variable confounds the effect of another. The opposite would also be true. Therefore, comparisons with other studies should be made with caution. For instance, temperature has been demonstrated to be an important factor in regulating bacterial activities ${ }^{2,25,39)}$, however, at our study site, periods of relatively high temperature $\left(22-28^{\circ} \mathrm{C}\right)$ usually coincided with suboxic or reduced overlying bottom water (negative Eh) with rather low DO concentrations (mostly $<1 \mathrm{mg} \mathrm{L}^{-1}$ ) (Fig. 4), and a strongly anoxic sediment surface (highly negative Eh) (Fig. 5). As a result, the effect of temperature would be weakened on an annual basis. It is also to be considered that although low rates of bacterial production were evident at low temperatures, a wide range of production rates have been observed at higher temperatures ${ }^{42)}$. This suggests that activities are most influenced by temperature in colder sediments, whereas at higher temperatures other factors assume greater importance ${ }^{44,48)}$.

Annual correlations may not be the best way to identify the ecological factors which regulated the APA in the ecosystem during a specific period of the year at the present site. Therefore, we tried to discern the most critical environmental factors on a short-term/seasonal basis by selecting two subsets of data and analyzing them separately as explained in the methods section. It was observed that from mid December to early June, when DO in the bottom environment was abundant $\left(\geq 2 \mathrm{mg} \mathrm{L}^{-1}\right)$, and temperature relatively low $\left(12-22^{\circ} \mathrm{C}\right)$, APA showed a highly significant $(\mathrm{p}<$ $0.001)$ and strong correlation with temperature $(\mathrm{r}=0.81)$ (Fig. 8A) and protein content $(\mathrm{r}=0.65)$ (Fig. 8B), and a negative correlation with DO $(\mathrm{p}<0.05 ; \mathrm{r}=-0.67)$ (Fig. $8 \mathrm{C})$ probably as a consequence of the fact that the DO in the bottom environment was reduced especially in spring-early summer due to temperature induced activity and a build up of stratification. Thus, from early winter to early summer, temperature and the protein content explained most of the variations in the APA. The significant impact of protein 

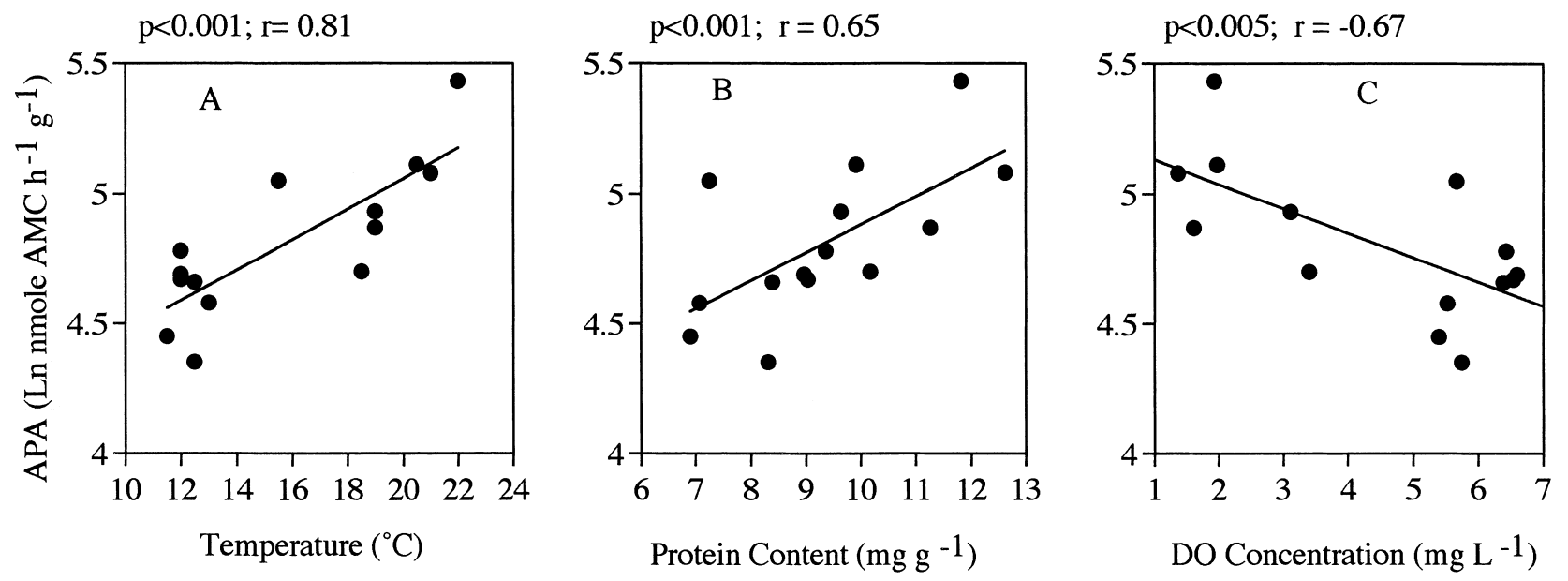

Fig. 8. Correlations between natural $\log (\mathrm{Ln})$ transformed APA in the surface sediment (on a dry matter basis) and temperature (A), protein content of the sediment (B), and DO concentration in overlying bottom water (C) during the period from early winter to early summer (mid December-early June).
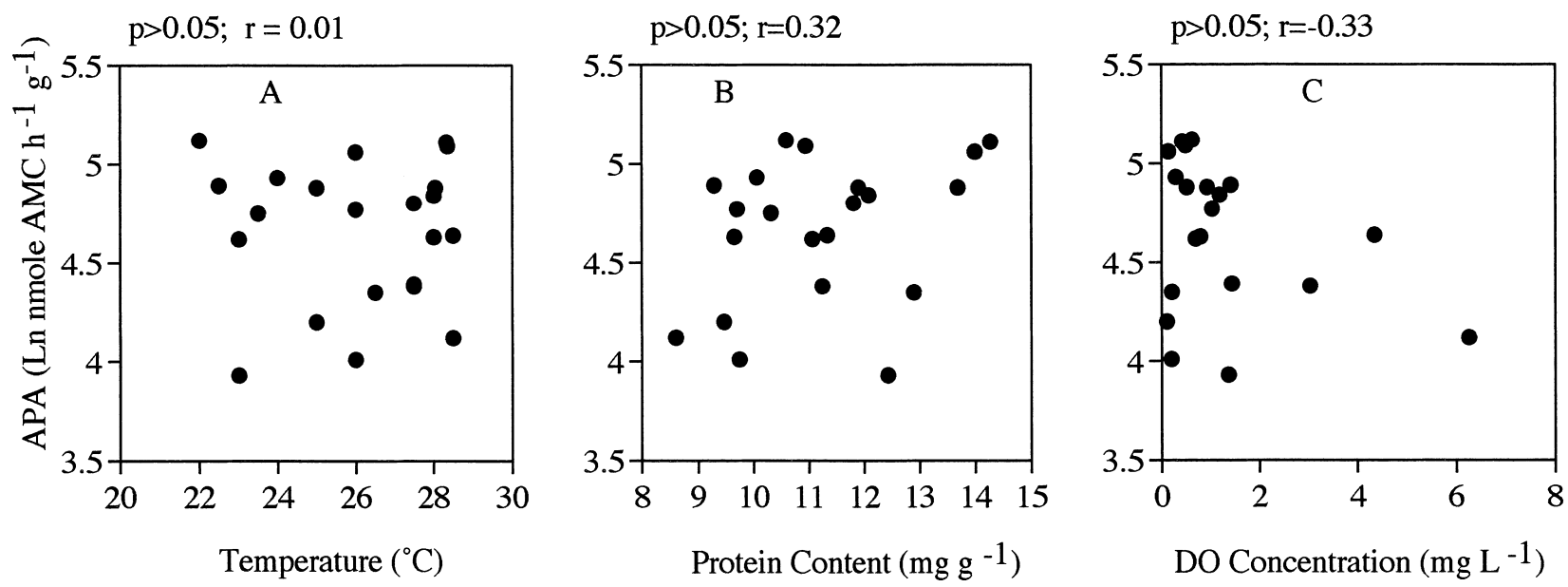

Fig. 9. Correlations between natural $\log (\mathrm{Ln})$ transformed APA in surface sediment (on a dry matter basis) and temperature (A), protein content of surface sediment (B), and DO concentrations (C) in the stratified water column during the summer (mid June to August-September).

content on APA is notable because the time frame (mid December-early June) does not cover a fish-growing period and hence, the amount of feed input around the sampling station would be low. This is also evident from the low protein content of surface sediment during this period (Fig. 2). In contrast, during the summer (mid June to August-September of both the years under study) when the temperature was high, APA no longer correlated with temperature ( $\mathrm{p}>$ 0.05) (Fig. 9A) or protein content (Fig. 9B). Interestingly, there was a rather weak negative correlation $(0.05<\mathrm{p}<$ $0.10 ; \mathrm{r}=-0.33$ ) between APA and DO concentration during this period (Fig. 9C), probably because of an abrupt but temporary increase in the DO concentration of bottom water during the summer (late June to August-September) resulting from a disturbance of the water column caused by typhoons and/or high wind, which suppressed the APA of the surface sediment (compare Fig. 4 and Fig. 7). Thus, during summer when the DO concentration is low $\left(<1 \mathrm{mg} \mathrm{L}^{-1}\right)$ and sediment is highly reduced, anaerobic or microaerophillic bacteria dominate the bacterial community whose activities were suppressed due to abrupt increases in DO while at the same time, activities of aerobic bacteria which might be in a dormant stage due to the low DO did not increase due to the lag phase.

Although, APA is only an estimate of the potential in situ activity, the results of the present study demonstrate that 
most of the hydrolysis of protein takes place in surface sediment following the autumn mixing or just prior to the build up of density stratification in early summer, as these are the periods when there is a combination of relatively high temperature and dissolved oxygen in the bottom environment. The hydrolysis is quite constrained in the winter (JanuaryFebruary) and summer (July-August). Furthermore, the present study illustrates that for an ecosystem which witnesses a combination of density stratification and considerable alterations in ecological variables during an annual cycle, statistical analyses performed after treating all the data points equally (for the whole year) may confound the impacts of environmental variables which might have regulated the activities on a short term basis. For that matter, although temperature and protein contents seem to play important roles in regulating the proteolytic activities from late winter to early summer, their impact was almost masked when analyses were made on an annual basis. Therefore, we are of the view that correlation analyses ought to be made only after serious consideration of the ecological conditions of the study site.

\section{Acknowledgments}

The authors thank the staff of the Marine Biological Research Center Usa (Japan) and students of the laboratory of Aquatic Environmental Science, Faculty of Agriculture, Kochi University (Japan) for their help in sampling. The study was supported in part by a grant-in-aid for the Bio Renaissance Program from the Ministry of Agriculture, Forestry and Fisheries (BRP-98-II-B-1).

\section{References}

1) Alongi, D.M. 1988a. Bacterial productivity and microbial biomass in tropical mangrove sediments. Mar. Ecol. 15: 59-79.

2) Alongi, D.M. 1988b. Microbial-meiofaunal interrelationships in some tropical inter tidal sediments. J. Mar. Res. 46: 349-365.

3) Alongi, D.M., K.G. Boto and F. Tirendi. 1989. Effect of exported mangrove litter on bacterial productivity and dissolved organic carbon fluxes in adjacent tropical near shore sediments. Mar. Ecol. Prog. Ser. 56: 133-144.

4) Alongi D.M., F. Tirendi and L.A. Trott. 1999. Rates and pathways of benthic mineralization in extensive shrimp ponds of the Mekong delta, Vietnam. Aquaculture 175: 269-292.

5) AOAC. 1984. Animal feed, p. 152-167. In S. William (ed.), Official methods of analysis of the AOAC. AOAC, Arlington, Virginia, USA.

6) APHA. 1985. Chlorophyll, p. 1067-1072. In M.A.H. Franson (ed.), Standard methods for the examination of waste water (15th edn.). American Public Health Association, Washington, DC.

7) Boschker, H.T.S. and T.E. Cappenberg. 1998. Patterns of extra- cellular enzyme activities in littoral sediments of Lake Gooimeer, The Netherlands. FEMS Microbiol. Ecol. 25: 79-86.

8) Capone, D.G. and J.E. Bauer. 1992. Microbial processes in coastal pollution, p. 191-237. In E.R. Mitchell (ed.), Environmental microbiology. Wiley-Liss INC.

9) Chróst, R.J. 1990. Microbial ectoenzymes in aquatic environments. p. 47-78. In J. Overbeck and R.J. Chróst (ed.), Aquatic microbial ecology: biochemical and molecular approaches. Springer-Verlag, New York.

10) Chróst, R.J. 1991. Environmental control of the synthesis and activity of aquatic microbial ectoenzymes. p. 29-59. In R.J. Chróst (ed.), Microbial enzymes in aquatic environments. Springer-Verlag, New York.

11) Dowd, J.E. and D.S. Riggs. 1965. A comparison of estimates of Michaelis-Menten kinetic constants from various linear transformations. J. Biol. Chem. 240: 863-869.

12) Foy, R.H. and R. Rosell. 1991. Loadings of nitrogen and phosphorus from a Northern Ireland fish farm. Aquaculture 96: 17-30.

13) Fukami, K., B. Meier and J. Overbeck. 1991a. vertical and temporal changes in bacterial production and its consumption by heterotrophic nanoflagellates in a north German eutrophic lake. Arch. Hydrobiol. 122: 129-145.

14) Fukami, K., N. Murata, Y. Morio and T. Nishijima. 1996. Distribution of heterotrophic nanoflagellates and their importance as the bacterial consumer in a eutrophic coastal sea water. J. Oceanogr. 52: 399-407.

15) Fukami, K., T. Nishijima, H. Murata, S. Doi and Y. Hata. 1991. Distribution of bacteria influential on the development and the decay of Gymnodinium nagasakiense red tide and their effects on algal growth. Nippon Suisan Gakkaishi 57: 2321-2326.

16) Goldman, J.C., C.D. Taylor and P.M. Gilbert. 1981. Nonlinear time course uptake of carbon and ammonium by marine phytoplankton. Mar. Ecol. Prog. Ser. 6: 137-148.

17) Hall, P.O.J., O. Holby, S. Kolberg and M.O. Sumuelsson. 1992. Chemical fluxes and mass balances in a marine fish cage farm. IV. Nitrogen. Mar. Ecol. Prog. Ser. 89: 81-92.

18) Hoppe, H.G. 1983. Significance of exoenzymatic activities in the ecology of brackish water: measurements by means of methylumbelliferyl substrates. Mar. Ecol. Prog. Ser. 11: 299-308.

19) Hoppe, H.G., S.J. Kim and K. Gocke. 1988. Microbial decomposition in aquatic environments: combined processes of extracellular enzyme activity and substrate uptake. Appl. Environ. Microbiol. 54: 784-790.

20) Jackson, C.R., C.M. Foreman and R.L. Sinsabaugh. 1995. Microbial enzyme activities as indicators of organic matte processing rates in a Lake Erie coastal wetland. Freshwater Biol. 34: 329342.

21) Johnsen, R.I., O. Grahl-Nielson and B.T. Lunestad. 1993. Environmental distribution of organic waste from a marine fish farm. Aquaculture 118: 229-244.

22) Johnson, K.M., C.M. Burney and J.M.N. Sieburth. 1981. Enigmatic marine ecosystem metabolism measured by direct diel $\mathrm{CO}_{2}$ and $\mathrm{O}_{2}$ flux in conjunction with DOC release and uptake. Mar. Biol. 65: 49-60.

23) Karner, M. and G.J. Herndl. 1992. Extracellular enzymatic activity and secondary production in free-living and marine-snow-associated bacteria. Mar. Biol. 111: 341-347.

24) King, G.M. 1986. Characterization of $\beta$-glucosidase activity in inter tidal marine sediments. Appl. Environ. Microbiol. 51: 373380. 
25) Li, W.K.W. and P.M. Dickie. 1987. Temperature characteristics of photosynthetic and heterotrophic activities: seasonal variations in temperate microbial plankton. Appl. Environ. Microbiol. 53: 2282-2295.

26) Lowery, O.H., N.J. Rosebrough, A.L. Farr and R.J. Randall. 1951. Protein measurement with the Folin phenol reagent. J. Biol. Chem. 193: 265-275.

27) Martinez, J. and F. Azam. 1993. Periplasmic aminopeptidase and alkaline phosphatase activities in a marine bacterium: implications for substrate processing in the sea. Mar. Ecol. Prog. Ser. 92: 89-97.

28) Mayer, L.M. 1989. Extracellular proteolytic enzyme activity in sediments of an intertidal mudflat. Limnol. Oceanogr. 34: 973981.

29) McCaig, A.E., C.J. Phillips, J.R. Stephen, G.A. Kowalchuk, S.M. Harvey, R.A. Herbert, T.M. Embley and J.I. Prosser. 1999. Nitrogen cycling and community structure of proteobacterial $\beta$-subgroup ammonia oxidizing bacteria within polluted marine fish farm sediments. Appl. Environ. Microbiol. 65: 213-220.

30) Meyer-Reil, L.A. 1983. Benthic response to sedimentation events during autumn to spring at a shallow water station in the western Kiel Bight. 2. Analysis of benthic bacterial populations. Mar. Biol. 77: 247-256.

31) Meyer-Reil, L.A. 1986. Measurement of hydrolytic activity and incorporation of dissolved organic substrates by microorganisms in marine sediments. Mar. Ecol. Prog. Ser. 31: 143-149.

32) Meyer-Reil, L.A. 1987. Seasonal and spatial distribution of extracellular enzymatic activities and microbial incorporation of dissolved organic substrates in marine sediments. Appl. Environ. Microbiol. 53: 1748-1755.

33) Meyer-Reil, L.A. 1990. Microorganisms in marine sediments: considerations concerning activity measurements. Arch. Hydrobiol. Beih. 34: 1-6.

34) Meyer-Reil, L.A. and M. Köster. 1992. Microbial life in pelagic sediments: the impact of environmental parameters on enzymatic degradation of organic material. Mar. Ecol. Prog. Ser. 81: 65-72.

35) Moriarty, D.J.W. and P.C. Pollard. 1981. DNA synthesis as a measure of bacterial productivity in seagrass sediments. Mar. Ecol. Prog. Ser. 5: 151-156.

36) Novitsky, J.A. 1983. Microbial activity at the sediment-water interface in Halifax Harbor, Canada. Appl. Environ. Microbiol. 45: 1761-1766.
37) Patel, A.B., K. Fukami and T. Nishijima. 2000. Regulation of seasonal variability of aminopeptidase activities in surface and bottom waters of Uranouchi Inlet, Japan. Aquat. Microb. Ecol. 21: 139-149.

38) Pedersen, A.U., J. Berntsen and B.A. Lomstein. 1999. The effect of eelgrass decomposition on sediment carbon and nitrogen cycling: A controlled laboratory experiment. Limnol. Oceaongr. 44: 1978-1992.

39) Pomeroy, L.R. and W.J. Wiebe. 1988. Energetics of microbial food webs. Hydrobiologia. 159: 7-18.

40) Poremba, K. 1995. Hydrolytic enzymatic activity in deep-sea sediments. FEMS Microbiol. Ecol. 16: 213-222.

41) Porter, K.G. and Y.S. Feig. 1980. The use of DAPI for identifying and counting aquatic microflora. Limnol. Oceanogr. 25: $943-$ 948.

42) Sanders, B.C. and J. Kalff. 1993. Factors controlling bacterial production in marine and fresh water sediments. Microb. Ecol. 26: 79-99.

43) Schallenberg, M., J. Kalff and J.B. Rasmussen. 1989. Solutions to problems in enumerating sediment bacteria by direct counts. Appl. Environ. Microbiol. 55: 1214-1219.

44) Shiah, F. and H.W. Ducklow. 1994. Temperature regulation of heterotrophic bacterioplankton abundance, production. and specific growth rate in Chesapeake Bay. Limnol. Oceanogr. 39: 1243-1258.

45) Velji, M.I. and L.J. Albright. 1986. Microscopic enumeration of attached marine bacteria of seawater, marine sediment, fecal matter, and kelp blade samples following pyrophosphate and ultrasound treatments. Can. J. Microbiol. 32: 121-126.

46) Venrick, E.L., J.R. Beers and J.F. Heinbokel. 1977. Possible consequences of containing microplankton for physiological rate measurements. J. Exp. Mar. Biol. Ecol. 26: 55-76.

47) Wellsbury, P., R.A. Herbert and R.J. Parkes. 1996. Bacterial activity and production in near -surface estuarine and freshwater sediments. FEMS Microbiol. Ecol. 19: 203-214.

48) Wikner, J. and A. Hagström. 1991. Annual study of bacterioplankton community dynamics. Limnol. Oceanogr. 36: 13131324.

49) Yu, W., W.K. Dodds, M.K. Banks, J. Skalsky and E.A. Strauss. 1995. Optimal staining and sample storage time for direct microscopic enumeration of total and active bacteria in soil. Appl. Environ. Microbiol. 61: 3367-3372. 